\title{
Exploring Opportunities for Enhancing Innovation in Agriculture: The Case of Cocoa (Theobroma cacao L.) Production in Ghana
}

\author{
F. Aneani ${ }^{1}$, R. Adu-Acheampong ${ }^{1} \&$ O. Sakyi-Dawson ${ }^{2}$ \\ ${ }^{1}$ Cocoa Research Institute of Ghana, P. O. Box 8, Tafo-Akim, Ghana \\ ${ }^{2}$ College of Agriculture and Consumer Sciences, Department of Agricultural Extension, P. O. Box 68, Legon \\ Accra, Ghana \\ Correspondence: F. Aneani, Cocoa Research Institute of Ghana, P. O. Box 8, Tafo-Akim, Ghana. E-mail: \\ franeani@yahoo.com
}

Received: June 11, 2017 Accepted: July 1, 2017 Online Published: October 27, 2017

doi:10.5539/sar.v7n1p33 URL: https://doi.org/10.5539/sar.v7n1p33

\begin{abstract}
An exploratory study was conducted to identify opportunities to enhance innovation in the cocoa sector in Ghana. The specific objectives were to identify the key stakeholders in the cocoa industry, and elicit farmers and other stakeholders' perceptions on cocoa production and marketing practices, as well as the inherent constraints and opportunities. The study involved literature review of published information and the use of Participatory Rural Appraisal (PRA) tools such as focus group discussion, problem tree analysis, seasonal calendar, and ranking techniques to elicit information from the respondents and purchasing clerks in the Eastern and Western Regions of Ghana. The problem tree analysis indicated that low cocoa incomes were due to low cocoa yields which were in turn caused by high incidence of pest and diseases such as capsids/black pod/cocoa swollen shoot virus disease (CSSVD), declining soil fertility and use of unapproved planting materials. The seasonal calendar analysis indicated that most cocoa farmers were financially constrained, experience high labour availability and cost from May to July during which farm activities are high. Based on the study, researchers recommend that the Ghana Cocoa Board (COCOBOD) intensifies its efforts in implementing the opportunities such as crop/livelihood diversification, provision of crop insurance against risk, etc. identified to enhance farmers' welfare and the development of the entire cocoa industry. Addressing these constraints requires collaboration among the various stakeholders in the sector, including the government, research and extension as well as smallholder farmers.
\end{abstract}

Keywords: agriculture, exploratory survey, constraints, opportunities, innovation, cocoa, production, marketing, Ghana

\section{Introduction}

\subsection{Background}

Agricultural development and poverty reduction require agricultural growth in productivity and incomes in rural communities. To achieve this, technologies and research findings must be shared with farmers and other stakeholders in the rural economy (Asenso-Okyere et al., 2008; Birner et al., 2006). Cocoa production has been a rural agricultural activity in Ghana and cocoa is an important cash crop to the economy of the country (MASDAR, 1998). It has contributed immensely to the socio-economic development of the country through the use of the foreign exchange and tax revenues earned by the government, the incomes obtained by cocoa farmers and other workers in the cocoa industry. According to MASDAR report (1998), cocoa cultivation is influenced by many factors and power relationships. These include various types of labour contracts, intra-household relations and indigenous land tenure systems. They are also closely linked to traditional political systems.

After introduction in the country, cocoa production was rapid with the first cocoa export occurring in 1885, and reached its peak of 568000 tonnes in 1965, after which it started to decline until 1982 with an output of 159000 tonnes in 1983/84 (Fig. 1) when drought and bush fires were intense (MASDAR, 1998). The decline in cocoa output, which affected the exported volumes (Fig. 2) and revenues, was attributed to the fact that the cocoa sector faced many internal problems some of which impacted the entire economy. These problems included: increasing disease problems exacerbated by lack of chemicals and machinery to apply them; an aging tree stock; 
successive droughts in the late 1970s and early 80s; a rapidly deteriorating transport infrastructure which added to the inefficiencies of overstaffed marketing organization; and low producer prices that increased attractiveness of essential food crops and other perennial crops. Until the end of the wartime years cocoa farmers received world market prices less deductions for handling, freight and margins for the merchants (Ofosu, 1995). The Cocoa Marketing Board, now Ghana Cocoa Board (COCOBOD), currently playing regulatory role in the cocoa industry, was established in 1947 to stabilize producer prices and provide marketing services to the farmers.

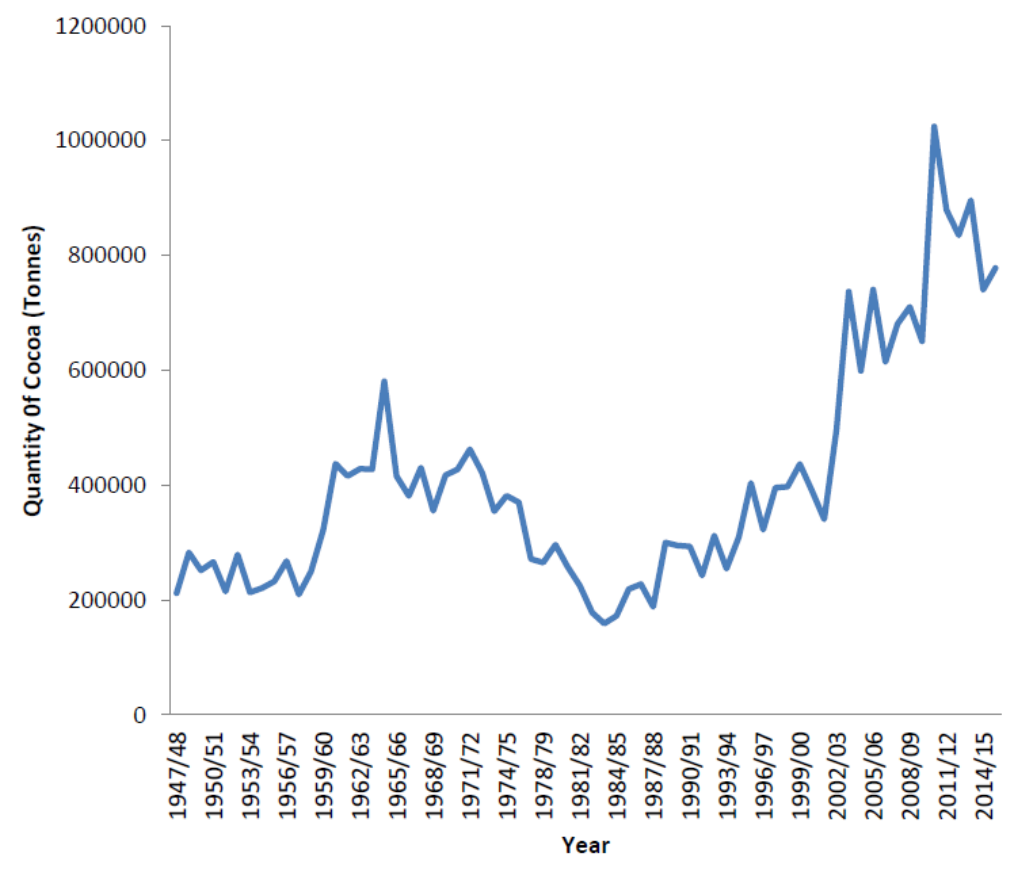

Figure 1. A Chart of Annual Cocoa Production Trend

Source: Ghana Cocoa Board (COCOBOD)

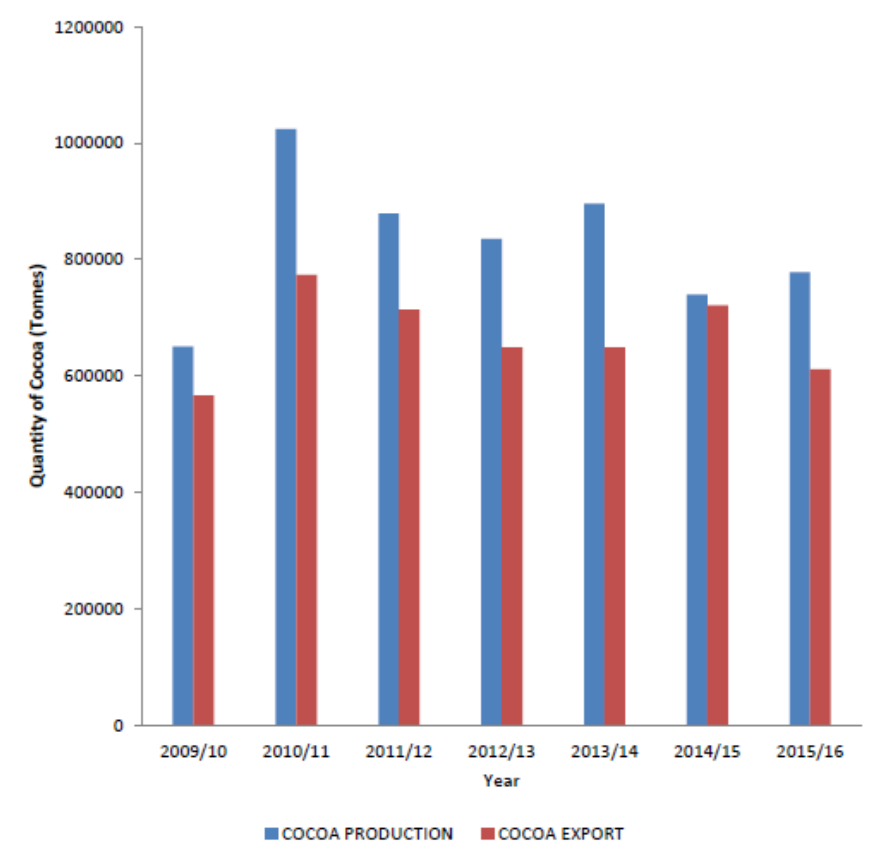

Figure 2. Annual Values of Cocoa Production and Export

Source: Ghana Cocoa Board (COCOBOD) 
Overall cocoa production has recently been increasing, but output per unit area is still low (400 kg/ha) compared with that of other producing countries such as Cote d'Ivoire $(1000 \mathrm{~kg} / \mathrm{ha})$ and Malaysia $(800 \mathrm{~kg} / \mathrm{ha})$. This increased yield was achieved through the implementation of Cocoa Disease and Pest Control (CODAPEC) and Cocoa High Technology (Hi-tech) programmes by Ghana Cocoa Board (COCOBOD) in response to the low adoption of CRIG technologies by the cocoa farmers (Henderson \& Jones, 1990; Donkor et al., 1991; MASDAR, 1998; Aneani et al., 2007). The low adoption may be due to linear transfer of the technologies to the farmers; that is, the modified Training and Visit system of technology and knowledge transfer involving Research-Extension-farmer linkage. This system placed too much emphasis on technical innovations to increase cocoa production and productivity (Asenso-Okyere et al., 2008; Hounkonnou et al., 2012).

Akerlof (1970) believes that institutions are developed to counter the negative impacts of the dealings among the stakeholders or actors such as asymmetric information. According to Johnson (1992), institutions are sets of habits, routines, rules, norms, and laws, which regulate the relations between people and shape human interactions. By reducing uncertainty and, therefore, amount of information needed for individual and collective action, institutions are fundamental building blocks in all societies. Institutions give incentives to economic agents to act in certain ways which are beneficial to them (Klein, 1996). This is obtained by lowering the uncertainty around technology application, cost of transactions and protecting property rights.

Convergence of Science: Strengthening Innovation Systems (CoS-SIS) is a follow-up of a previous research programme (2001-2006), "Convergence of Science" (CoS), which emphasized the use of participatory technology development (PTD) to enhance smallholder livelihoods (Van Huis et al., 2007). Though the application of PTD approach improved farmers' livelihoods by enhancing the adoption of technologies to increase production and hence incomes, there were uncontainable institutional factors which hampered opportunities for smallholders to obtain the benefits of PTD (Hounkonnou et al., 2012). Therefore, CoS-SIS experimented on how institutional change might open opportunities for farmers to gain from PTD. In the quest for institutional factors and other constraints in the cocoa industry, this exploratory study was commissioned as a collaborative study between CRIG and CoS-SIS programme of University of Ghana.

Cocoa was selected for the following reasons: National priority crop because of its potential for reducing poverty; it has a wide geographical coverage as it can be cultivated in six out of the ten administrative regions of the country; and it is a cash crop.

\subsection{Objectives of the Study}

The main objective of the study was to identify opportunities [an opportunity is defined here as a potential for a group of people to capture value, either through a change in their practices to exploit existing conditions or a change in institutional conditions that allow them to respond from their existing practices or both (Adjei-Nsiah et al., 2012)], challenges and factors that constrain the cocoa sector for solution. This will encourage investment in increased production, improved agricultural and environmental practices, reduce poverty, and enhance food security among smallholder farmers in Ghana.

The specific objectives were to:

Identify the key stakeholders in the cocoa industry.

Determine the nature of farmers and other stakeholders' perceptions on cocoa production and marketing practices.

Identify and assess the inherent constraints and opportunities.

\section{Methodology}

An exploratory study was conducted to test the CoS-SIS approach which adopts an interdisciplinary action research using an innovation system process in the study areas to identify technical, socio-economic, and institutional constraints in the cocoa industry for innovative solutions to provide cocoa farmers the opportunities for increased output and productivity. This design of the survey was adopted because of the exploratory nature and the fact that generally cocoa production is similar in all the cocoa growing regions.

\subsection{Description of the Study Areas and Sampling Procedure}

The exploratory study was conducted in some cocoa districts of the Eastern and Western Regions from March to August, 2013. Those districts in the Eastern were Akim Oda and Suhum while that of Western were Dunkwa, Sefwi Essam and Boako (Table 1). The communities surveyed in the Eastern included Akim Oda, Akim Swedru, Anum Apapam and Brekumanso whilst that of the Western Region were Meretweso, Achiase, Kwamebikrom, Adabokrom and Punnikrom (Table 1). The Eastern Region was included in the study because it was in this 
region that cocoa was initially introduced and cultivated extensively in the country (MASDAR, 1998). Also, the reason for choosing the Western Region was that this region is currently the frontier of cocoa production after gradual shift from Eastern, Ashanti, Central, and Volta Regions of the country. The Western Region now produces about half of the total cocoa production in Ghana for export (MASDAR, 1998).

Table 1. Locations, number of focus group discussions and participating stakeholders (farmers \& purchasing clerks)

\begin{tabular}{|c|c|c|c|c|c|c|c|}
\hline Region & District & Town/Village & $\begin{array}{l}\text { Number of focus } \\
\text { group discussions }\end{array}$ & $\begin{array}{l}\text { Numb } \\
\text { partici }\end{array}$ & $\begin{array}{l}\text { of farmer } \\
\text { ints }\end{array}$ & $\begin{array}{l}\text { Numb } \\
\text { clerks }\end{array}$ & $\begin{array}{l}\text { f purchasing } \\
\text { icipants }\end{array}$ \\
\hline \multirow{3}{*}{ Eastern } & & & & Male & Female & Male & Female \\
\hline & \multirow[t]{2}{*}{ Suhum } & Anum Apapam & 2 & 9 & 4 & \multirow[t]{2}{*}{-} & \multirow[t]{2}{*}{-} \\
\hline & & Brekumanso & 2 & 12 & 1 & & \\
\hline \multirow{8}{*}{ Western } & \multirow[t]{2}{*}{ Akim Oda } & Akim Oda & 2 & 10 & - & \multirow[t]{2}{*}{-} & \multirow[t]{2}{*}{ - } \\
\hline & & Akim Sweduro & 2 & 10 & 4 & & \\
\hline & \multirow[t]{2}{*}{ Dunkwa } & Meretweso & 1 & 16 & 1 & - & - \\
\hline & & Achiase & 1 & 11 & 6 & - & - \\
\hline & \multirow[t]{3}{*}{ Sefwi Essam } & Kwamebikrom & 1 & 14 & 1 & - & - \\
\hline & & Adabokrom & 1 & 12 & 1 & - & - \\
\hline & & Essam & 1 & & & 9 & - \\
\hline & Boako & Punnikrom & 1 & & & 16 & - \\
\hline Total & & & 14 & 94 & 18 & 25 & - \\
\hline
\end{tabular}




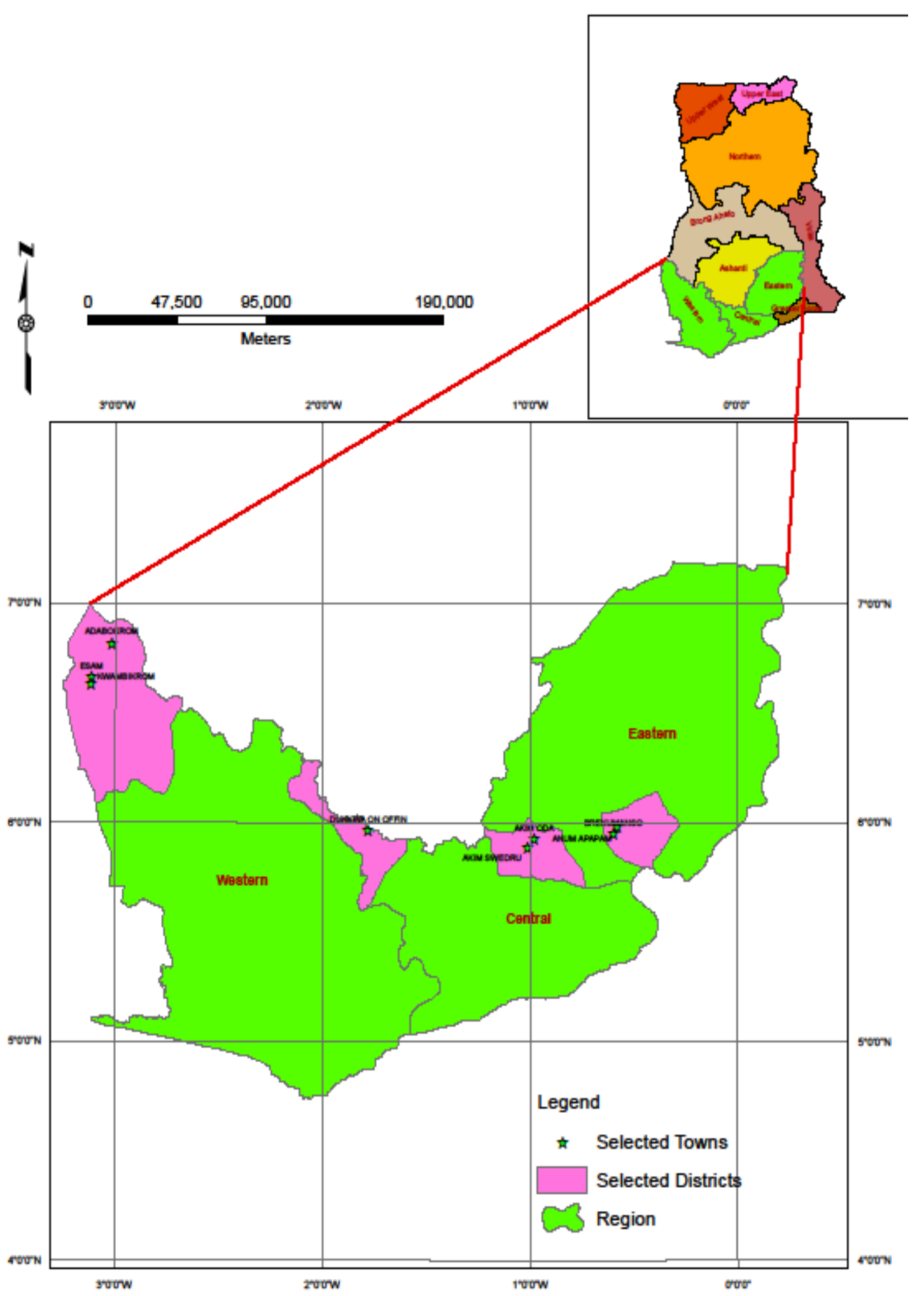

Figure 3. A map of Ghana indicating the regions, districts and communities surveyed

\subsection{Data Collection}

The study involved literature review and the use of Participatory Rural Appraisal (PRA) tools such as focus group discussion, problem tree, seasonal calendar, and ranking techniques to elicit information from the respondents and purchasing clerks in the study areas of Eastern and Western Regions of Ghana. Before the 
respondents were gathered into groups, the researchers contacted the chief farmer cocoa purchasing clerk in the community for briefing on the purpose of the survey, the types of information required, and the procedure for the discussion. Similarly, the groups were also briefed before the actual interview. Twelve focus groups of 10-17 farmers each were formed in four communities for the discussion using a checklist containing questions on input supply; technological, processing, marketing and institutional issues; and cocoa production constraints including illegal mining (galamsey). Another two focus groups of 6-10 purchasing clerks (PCs) of the various Licensed Buying Companies (LBCs) were formed in two communities for discussions on their operations and constraints, their relationship with the cocoa farmers, benefits/incentives farmers received from LBCs, and policy/institutional issues.

\subsection{Data Analysis}

Data were analyzed employing stakeholder analysis, content analysis, scoring and ranking techniques. Seasonal analyses were also conducted on amount of rainfall, labour availability for farm activities and farmers' cocoa incomes and expenditures to determine patterns and constraints. The stakeholder analysis entailed identifying farmers, farmer associations and organizations affected by cocoa production issues that CoS-SIS project seeks to address. The stakeholders were categorized according to their interest or role in the cocoa industry. The content analysis was conducted to reveal the patterns and trends in the qualitative data collected during the focus group discussions. Constraints or problems face by farmers in cocoa industry were identified using problem tree analysis. This analysis involved the identification of the causes and effects of a specific problem which is assumed to be trunk of a tree, with the roots and leaves representing the causes and effects respectively. Then, the constraints were scored and ranked depending on degree of importance. In the scoring process, 20 stones were chosen to represent the number of identified constraints and the farmers scored each constraint by assigning a specific number of stones out of the total. The scores were averaged and ranked to determine the final position of a constraint among the others. Seasonal analyses were also conducted on amount of rainfall, labour for farm activities and farmers' cocoa incomes to determine patterns and constraints. The researchers did this by allowing the respondents to allocate a set of 15 stones among the months of the year, with number of stones given to each month representing the intensity.

\section{Results}

\subsection{Stakeholder Analysis}

This study identified key stakeholders/actors in the cocoa industry with their specific roles, locations and relationships. They comprised Ghana Cocoa Board (COCOBOD) with the subsidiaries such as the Cocoa Marketing Company (Ghana) Limited (CMC), the Cocoa Processing Company Limited (CPC), the Cocoa Research Institute of Ghana (CRIG), the Cocoa Swollen Shoot Virus Control Unit (CSSVDCU), now renamed Cocoa Health and Extension Division (CHED), the Quality Control Company Ltd (QCCL); the Private Licensed Buying Companies (LBCs); cocoa farmers; and farmer association, with their specific roles, locations and relationships in the cocoa industry (Table 2). The relationship analysis demonstrated that there are dependency and cooperation among the stakeholders. These relations involve forward and backward linkages. Forward linkage represents the provision of inputs into the cocoa production process while backward linkage entails the utilization of the output through value addition to produce cocoa butter and liquor which are used in the confectionery and cosmetic industries. 
Table 2. Stakeholders and their functions in the cocoa industry

\begin{tabular}{|c|c|c|c|c|}
\hline No. & Name Stakeholder & Function/Role played in the cocoa industry & $\begin{array}{l}\text { Location of } \\
\text { Head Office }\end{array}$ & $\begin{array}{l}\text { Relationship } \\
\text { with other } \\
\text { institutions }\end{array}$ \\
\hline 1 & $\begin{array}{l}\text { Ghana Cocoa Board } \\
\text { (COCOBOD) }\end{array}$ & $\begin{array}{l}\text { COCOBOD is a statutory public board established by Ordinance in } 1947 . \\
\text { In line with the liberalization policy of the Government, COCOBOD now } \\
\text { formulate policies, monitors and regulates the operations of the cocoa } \\
\text { industry in Ghana. }\end{array}$ & Accra & $\begin{array}{l}2 ; 3 ; 4 ; 5 ; 6 ; 7 ; \\
8 ; 9\end{array}$ \\
\hline 2 & $\begin{array}{l}\text { The Cocoa Marketing } \\
\text { Company (Ghana) Limited } \\
(\mathrm{CMC})\end{array}$ & $\begin{array}{l}\mathrm{CMC} \text { is responsible for the external marketing of cocoa beans as well as } \\
\text { cocoa liquor, cocoa butter and cocoa cake, produced by the Cocoa } \\
\text { Processing Company Limited. }\end{array}$ & Tema & $1 ; 3 ; 6$ \\
\hline 3 & $\begin{array}{l}\text { The Cocoa Processing } \\
\text { Company Limited (CPC) }\end{array}$ & $\begin{array}{l}\text { CPC processes raw cocoa beans into semi-finished products such as cocoa } \\
\text { butter, liquor, cake or powder. It also manufactures Golden Tree Brand } \\
\text { Chocolate, Couverture "Pebbles" and Vitaco Instant Chocolate Drink. }\end{array}$ & Tema & $1 ; 2 ; 6 ; 8$ \\
\hline 4 & $\begin{array}{l}\text { The Cocoa Research } \\
\text { Institute of Ghana (CRIG) }\end{array}$ & $\begin{array}{l}\text { CRIG investigates problems of diseases and pests of cocoa, kola, coffee, } \\
\text { sheanut, cashew and the tallow tree (Pentadesmabutyracea), soil fertility, } \\
\text { and good agricultural practices, develop planting materials for use by } \\
\text { farmers e.g. cocoa seedlings/clones and coffee clones, with the view to } \\
\text { increasing yield and farmers' income; and conducts research into the } \\
\text { development of other products from cocoa waste and by-products. }\end{array}$ & $\begin{array}{l}\text { New } \\
\text { Tafo-Akim }\end{array}$ & $1 ; 5 ; 7 ; 9$ \\
\hline 5 & $\begin{array}{l}\text { The Cocoa Swollen Shoot } \\
\text { Virus Disease Control Unit } \\
\text { (CSSVDCU), now renamed } \\
\text { as Cocoa Health and } \\
\text { Extension Division (CHED) }\end{array}$ & $\begin{array}{l}\text { CSSVDCU/CHED is responsible for the control of cocoa swollen shoot } \\
\text { virus disease and cocoa extension. }\end{array}$ & Accra & $1 ; 4 ; 7 ; 9$ \\
\hline 6 & $\begin{array}{l}\text { The Quality Control } \\
\text { Company Ltd (QCCL) }\end{array}$ & $\begin{array}{l}\text { QCCL is responsible for inspection, grading, and sealing of cocoa, coffee } \\
\text { and sheanut for export; and for fumigation and storage of cocoa. }\end{array}$ & Tema & $1 ; 2 ; 3 ; 8$ \\
\hline 7 & $\begin{array}{l}\text { The Seed Production Unit } \\
\text { (SPU) }\end{array}$ & $\begin{array}{l}\text { The SPU is responsible for the multiplication and distribution of improved } \\
\text { cocoa and coffee planting materials to farmers. }\end{array}$ & Accra & $1 ; 4 ; 5 ; 9$ \\
\hline 8 & $\begin{array}{l}\text { The Private Licensed } \\
\text { Buying Companies (LBCs) } \\
\text { and Hauliers }\end{array}$ & $\begin{array}{l}\text { The LBCs are responsible for domestic purchasing and hauling of cocoa } \\
\text { beans to the port for export. }\end{array}$ & $\begin{array}{l}\text { Accra and } \\
\text { Kumasi }\end{array}$ & $1 ; 2 ; 3 ; 9$ \\
\hline 9 & $\begin{array}{l}\text { The farmers represented by } \\
\text { Ghana Cocoa, Coffee and } \\
\text { Sheanut Farmers } \\
\text { Association (GCCSFA) }\end{array}$ & $\begin{array}{l}\text { The farmers actually produce the cocoa at the farm level. The GCCSFA is } \\
\text { responsible for the procurement and distribution of agro-chemicals } \\
\text { (insecticides, herbicides and fungicides) and spraying machines. It also } \\
\text { acts as a representative body to articulate farmers' opinions at national } \\
\text { level. }\end{array}$ & Accra & $1 ; 4 ; 5 ; 7 ; 8$ \\
\hline
\end{tabular}

\subsection{Cocoa Production}

\subsection{Identification of Constraints and Opportunities in Cocoa Production and Marketing}

\subsubsection{Problem Tree Analysis}

The results of the problem tree analysis conducted with the respondents (Fig. 3) indicated that low incomes of farmers from their cocoa farms was the effect of low yields which were caused by high incidence of pests and diseases such as capsids, black pod and CSSVD; declining soil fertility; and use of unapproved planting materials. Also, high incidence of black pod disease resulted from limited disease and pest control practices which were in turn caused by poor access to credit, high cost of inputs, inadequate access to other inputs/agro-chemicals and labour dynamics. The inadequate access to inputs/agro-chemicals was attributed to poor implementation of the mass spraying policy, that is, CODAPEC programme and late supply of inputs. This was mainly due to the non-liberalized input supply.

Low cocoa yields were caused by illegal mining, Galamsey, which was attributable to labour dynamics. Declining soil fertility was attributed to limited soil management practices which were in turn ascribed to inadequate knowledge. The inadequate knowledge of the farmers was also caused by poor/insufficient extension service.

Planting of unapproved materials was caused by inadequate access to approved seeds and seedlings which was in 
turn caused by limited resources of the Seed Production Unit (SPU). In addition, the limited access to approved seeds and planting materials was attributed to the policy of allocation to CSSVDCU farmers which in turn was influenced by inequity in distribution of seed gardens.

\subsubsection{Seasonal Calendar Analysis}

The results of the seasonality analysis conducted with the respondents are presented in Figure 4 . Some explanations were given at Adabokrom about the patterns revealed by the seasonal calendar. From January to March the hired labourers had money and therefore would not want to offer their labour for money while the farmers' labour demand was also low due to low farm activities. However, from May to July, the labourers and farmers needed money and there were also high farm activities. For October, November and December, there were low rainfall, low farm activity, both farmers and labourers had money, and nnoboa (exchange labour) was mostly used. The implication of these explanations is that most cocoa farmers are financially constrained in hiring labour which is available from May to July during which there are high farm activities.

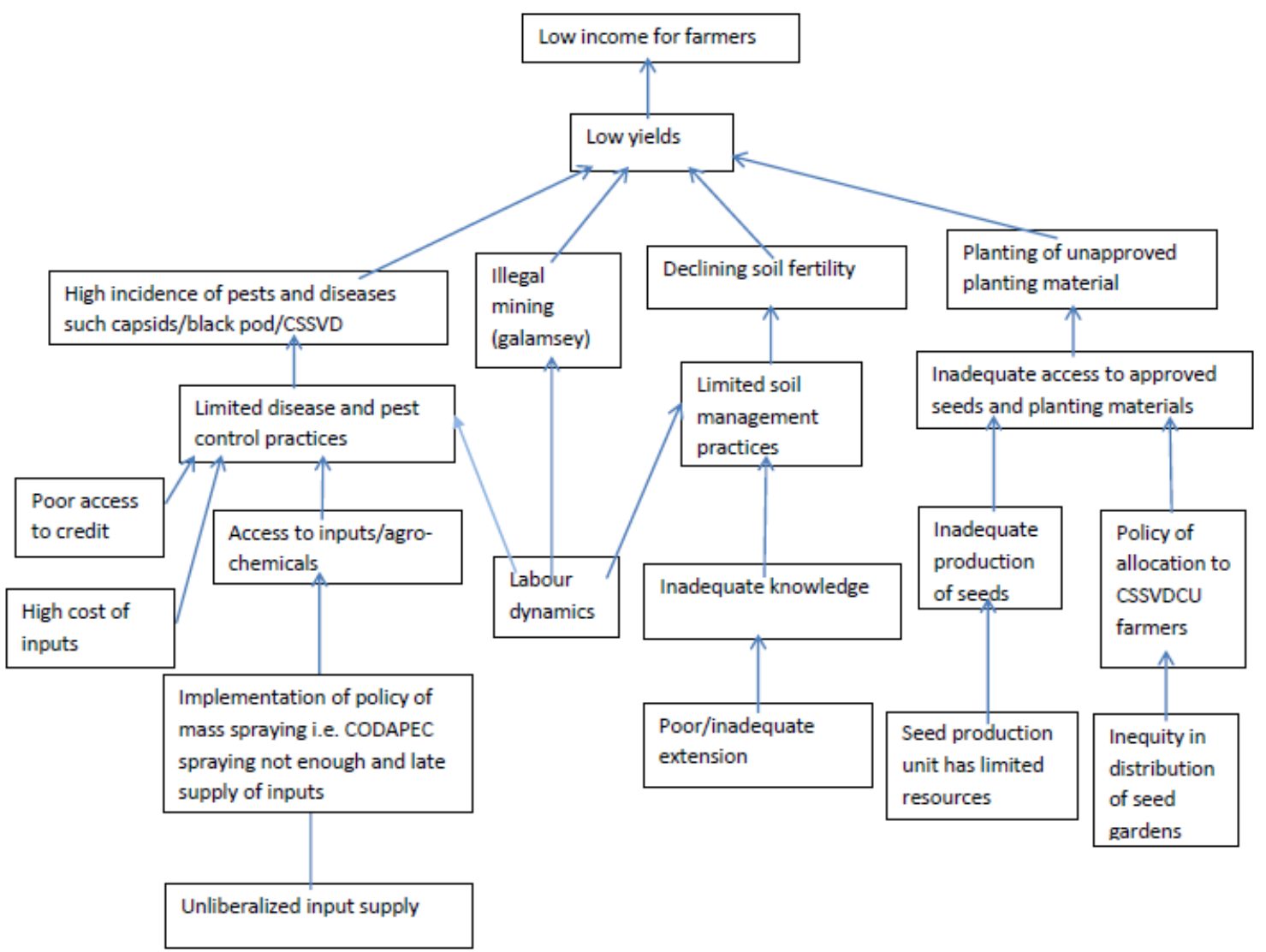

Figure 3. Problem tree diagram

Source: Exploratory survey (2013) 


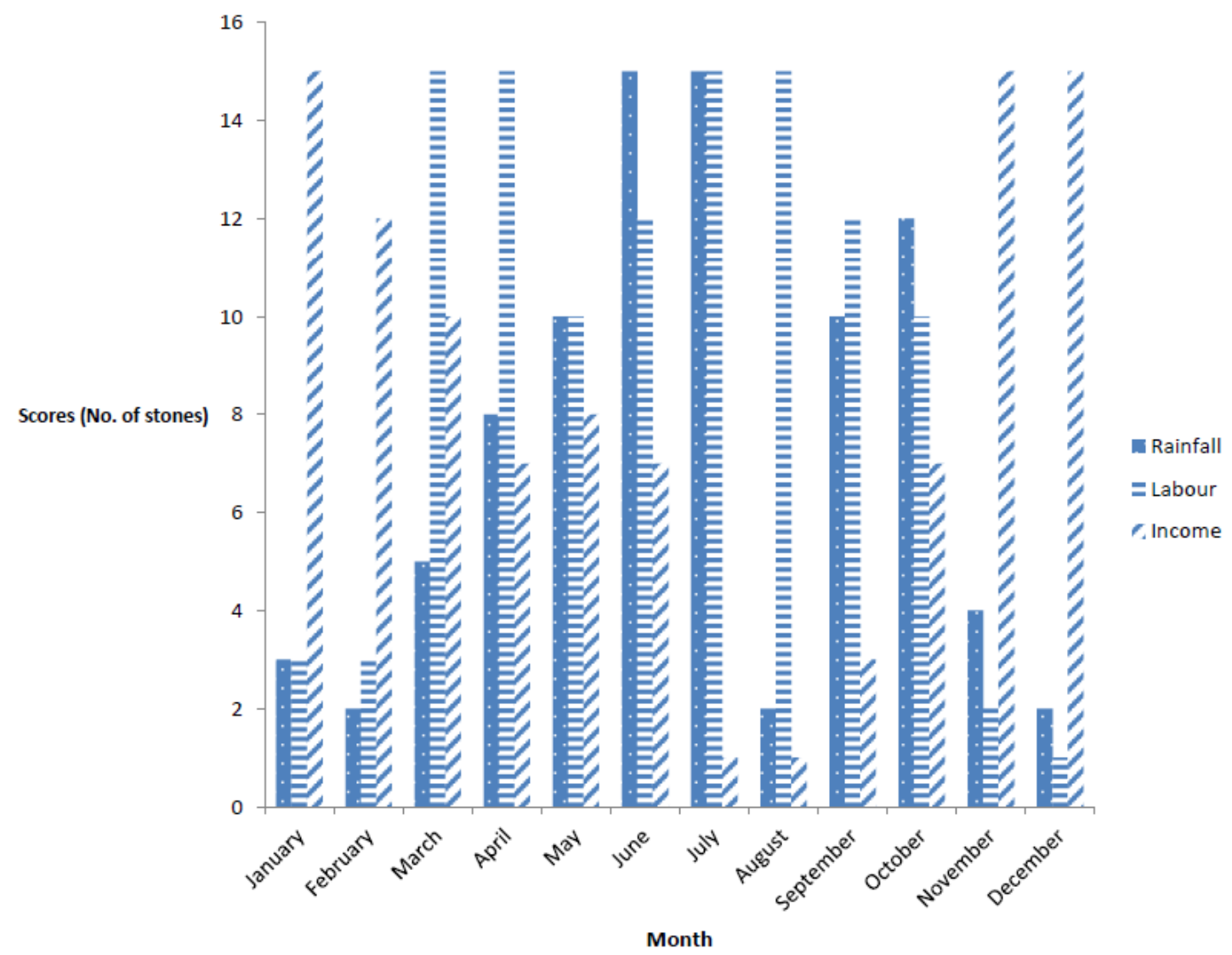

Figure 4. Seasonal calendar of rainfall, hired labour and income

Source: Exploratory survey (2013)

\subsubsection{Perception of Participants on Cocoa Production Constraints/Opportunities}

The respondents chose poor status of farming, low incomes, low employment opportunities and poor rural facilities as their most important constraints. However, poor health arising largely from poor standard of rural life and medical facilities was regarded as the least constraint (Appendix A, Table 1). The identified constraints of the participants were categorized into technical, socio-economic, social and institutional. The analysis of the scores and rankings of the constraints identified by the respondents indicated that they placed more emphasis on the socio-economic and social constraints than the technical and institutional ones (Table 3).

Table 3. Importance of technical, socio-economic, social and institutional constraints indicated by their average scores and rankings

\begin{tabular}{llll}
\hline Category of constraints & Average score & Average ranking & Actual position/ranking \\
\hline Technical & 189.9 & 21.1 & 3 \\
Socio-economic & 290.6 & 11.8 & 1 \\
Social & 225.2 & 16.9 & 2 \\
Institutional & 161.8 & 22.6 & 4 \\
\hline
\end{tabular}

\subsubsection{Policy/Institutional Issues}

\subsubsection{Perception of Farmer Respondents on Institutional Issues}

According to the respondents in Brekumanso, there were several institutional factors such as taboos, values and norms which were laid down by their forefathers and they had been traditionally accepted by the communities. The taboos, values and norms sometimes caused delays in performing farm activities. For instance, certain days are prohibited for farming and this could delay timely application of chemicals to control pests and diseases.

The respondents also thought that government policies on inputs and pricing were major institutional constraints. Excessive bureaucracy within government sector caused delay in the supply of necessary inputs like fertilizers 
and seedlings and this impacted negatively on cocoa production. Lower producer price also negatively affected farmers' incomes and livelihoods.

\subsubsection{Perception of Purchasing Clerk Respondents on Institutional Issues}

The results of the focus group discussion with some cocoa purchasing clerks at Punnikrom and Essam in the Western Region are presented in Table 4. It can be deduced from the results evidence of operational and financial injustice the Purchasing Clerks (PC's) are subjected to by their licensed buying companies (LBC's). For instance, the PC's are made to pay the sealing and sieving costs instead of their LBC's when sub-standard cocoa was detected at the port by the quality control agents. Also, there was a concern of low amount of commission per bag of purchased cocoa paid to them. The PC's also responded to these injustices by malpractices such as adjustment of weighing scales to the detriment of the cocoa farmers. In addition, the results indicated inadequate incentives provided by the LBC's to their purchasing clerks and the farmers which negatively affected cocoa purchasing. 
Table 4. Results of the focus group discussions with some cocoa purchasing clerks at Punikrom (Boako District) and Essam (Sefwi Essam District)

\begin{tabular}{ll}
\hline Issue & Discussion \\
\hline Operations of LBC's/PC's & From the discussion with the purchasing clerks in the Western Region, the respondents \\
& indicated that the Licensed Buying Companies (LBCs) and their Purchasing Clerks (PC's) \\
& were required by COCOBOD to purchase good quality cocoa beans for export. However, in \\
& the event of detecting a sub-standard cocoa at the port by the quality control agents after \\
& beans had been checked and sealed at the depot, only the PC's were made to bear the sealing \\
& and sieving costs instead of the LBCs. Also, the PC's had to attend meetings ("returns") \\
& every week at the district office for the collection of cocoa sacks and other obligations. All \\
& the transport expenses were borne by the PC's. Even some PC's pay for the cost of \\
& maintenance of the structure/warehouse use for cocoa purchases except for PBC.
\end{tabular}

Liberalization of internal cocoa marketing The respondents stated that the liberalization of internal cocoa purchasing had led to competition among the PC's which had put farmers at the advantage and thus, refused to process their cocoa beans as expected, resulting in poor quality beans. It had also led some PC's to pre-finance the farmers who were expected to sell their cocoa beans to them, but unfortunately some of these farmers did not and even failed to repay the loans and therefore, put the PC's into debts.

Segregation of the cocoa beans $\quad$ From the respondents, the segregation of the cocoa beans into flat, dark, black, and red beans posed some challenges to them. This was because the PCs sometimes could not get full bag of each of the above categories to be forwarded to the depot. Meanwhile the District Officers (DO's) after giving the money to the PC's expected in return the same number of bags per the amount given. Also, they could not send the 'add mixture' (a mixture of flat, black, red and dark beans) to the port since it would be rejected and the PC was surcharged with the resultant cost. Consequently, the PC's money for cocoa purchases became unavailable which affected cocoa buying.

Commission of the PCs on the purchased The respondents expressed concern about the low commission paid to the purchasing clerks. cocoa Purchasing clerks received one kilogramme of cocoa beans or GHC 3.30 as a commission per every $64 \mathrm{~kg}$ (1 bag) of cocoa beans purchased.

The non-payment of salaries to the PCs had brought about a lot of cheating in the cocoa marketing system because PCs bore the cost of paying security persons and labourers who re-dried and bagged the cocoa beans. Moreover, any cost incurred at the port was brought back to the PCs to pay even if it was caused by the DO's or the Quality Control Division (QCD) staff who were involved in certification. All these expenses were part of their little commission of GHC3.30 per bag.

Weighing scale adjustment The respondents also explained that District Officers deducted two kilogramme worth of cocoa beans from every $64 \mathrm{~kg}$ bag of cocoa purchased by the PC. This amount was deducted before the District Officer gave the money for the cocoa purchases. This resulted in the problem of scale adjustment. It was assumed that the two-kilogramme deducted was meant to cater for other official expenses (e.g., transport cost of beans to the depot), but that cost should not be borne by the purchasing clerk who operated on commission basis. However, with Produce Buying Company ( $\mathrm{PBC}$ ), the two-kilogramme deduction by the District Officers was disbursed on the basis of one kilogramme for cocoa sealing and grading and the other one kilogramme was used as buffer for the payment of debts of the PC's, otherwise the money was reserved for the PC's.

Incentives for purchasing clerks and According to the respondents, provision of no incentives to both PC's and farmers by some farmers LBC's discouraged them from working hard. Some companies/LBCs often provided inadequate incentives to the PC's and the farmers. The insufficient incentives made the sharing difficult and often led to conflicts between the PC's and the farmers, resulting in some PCs losing their customers (farmers). In addition, some PC's used their money to provide some incentives for the farmers just to sustain the business relationship.

Source: Survey Data 


\section{Discussion}

\subsection{Stakeholder Analysis}

A stakeholder analysis is a process for identifying stakeholders, understanding how they relate to an activity, their interests and needs, in order to identify opportunities and potential threats (Gosling \& Edwards, 2003). The study revealed the different actors/stakeholders in the cocoa industry and their respective roles played by them, locations and relationships among them. A stakeholder is a person, group or organizations with interests in or affected positively/negatively by an activity (cocoa production) (Gosling \& Edwards, 2003). The linkages among the stakeholders are cooperative and dependencies, which are indicated by numbers. These stakeholders can assist in the identification of technical and institutional constraints or issues during stakeholder workshops and serve as sources of members to innovation platforms such as the Concertation and Innovation Group (CIG) of CoS-SIS to be established in the cocoa districts.

\subsection{Problem Tree Analysis}

Problem Tree Analysis is a process of identifying the causes and effects of a problem by representing the causes, effects and problem with the roots, leaves and trunk of a tree, respectively. The problem tree analysis indicated that low cocoa incomes were due to low cocoa yields which were in turn caused by high incidence of pest and diseases such as capsids/black pod/CSSVD, declined soil fertility and planting of unapproved materials. The root causes of these situations were observed to be poor access to credit, high cost of inputs, inadequate and late mass spraying due to late supply of inputs caused by non-liberalized input supply, poor or inadequate extension, limited resources of the Seed Production Unit, and inequity in the distribution of seed gardens. These results show the persistent nature of the pest and disease constraints to cocoa production despite the dissemination of the recommended cocoa production technologies to farmers. This situation suggests the failure of the Training and Visit $(\mathrm{T} \& \mathrm{~V})$ system of technology transfer; that is, the linear transfer approach of farm innovations (Research-Extension-Farmer linkage) (Asenso-Okyere et al., 2008; Hounkonnou et al., 2012). In addition, the causes of the constraints appear to be mostly institutional (input/output marketing, credit provision and extension services) inadequacies in the implementation of policies and programmes.

\subsection{Seasonal Calendar Analysis}

The seasonal calendar analysis has indicated that most cocoa farmers were financially constrained in hiring labour which was available from May to July during which farm activities were high. This circumstance implies that farmers might need credit for the farm maintenance in this period. Hence, there is the need for further institutional changes to increase the efficiency of the support systems of cocoa production to enhance adoption of the technical innovations by the farmers.

\subsection{Ranking of Constraints}

Concerning the grouping and ranking of constraints into technical, socio-economic, social and institutional categories, although respondents appeared to emphasize more on socio-economic constraints, some of these constraints are seen to be institutional such as poor standard of cocoa buying and marketing as well as poor availability of planting materials (seedlings).

\subsection{Illegal Mining (Galamsey)}

The respondents identified Galamsey as one of the major constraint to cocoa production. By definition, it is an illegal mining involving extracting minerals with the absence of land rights, mining license, exploration and mineral transportation permit or any document that could legitimise the mining operations. In Ghana, land rights are held by the stool and families and concessions are granted to the illegal miners by the landowners, family heads and recently by individual family members. Galamsey, meaning "gather and sell" has gradually become serious problem in the areas that the miners operate. The problem involves environmental degradation including deforestation, land degradation, with water and air pollutions. Specifically, it can reduce cocoa yields and therefore cause economic insecurity because the topsoil which supports the growth of plants or a whole cocoa farm is destroyed. Galamsey is engaged in because of social and economic factors such as low income; lack of regulation enforcement; perverse incentives to avoid obtaining official land concessions for mining; and lack of education on environmental issues (Hilson, 2001). Though the communities highly appreciate the cash flow that illegal mining can bring, increased levels of social and medical ills, and disrespect for the rule of law are consequences associated with this mining (Amponsah-Tawiah \& Dartey-Baah, 2011). The galamsey operators claim that their activities have guaranteed jobs for the youth and reduced crime rate among others in the mining communities. They seem to be careless about the danger their activities pose to the inhabitants and the environment. For example, their operations can lead to livelihood threats through environmental pollution 
including contamination with heavy metals such as cadmium and mercury and pollutants such as cyanide which have the potential of going into the atmosphere and leading to contaminated freshwater sources, drop in fish populations and declining crops yields (Hilson \& Putter, 2005).

\subsection{Innovation}

\subsubsection{Technical Innovations}

The industry is supported with research by Cocoa Research Institute of Ghana which develops cocoa production technologies for adoption by farmers to increase cocoa output and yield per hectare. Technologies that have been developed encompass application of insecticides, fungicides, and herbicides to control capsids/mirids (Awudzi et al., 2009; Awudzi et al., 2012), black pod disease (Opoku et al., 2004; Opoku et al., 2007), and weeds, respectively (CRIG, 2014). There is also the cutting out and burning of cocoa trees infected with cocoa swollen shoot virus disease (CSSVD) (Domfeh et al., 2008; Ameyaw et al., 2013). Others include fertilizer application to replenish depleted soil nutrients of old cocoa soils (CRIG, 2011; CRIG, 2014), and the use of improved planting materials in the form of hybrid seeds/seedlings to enhance yields (CRIG, 2007). There is also the utilization of fermentation trays and boxes to ferment cocoa beans for improved quality (CRIG, 1996; Aneani \& Asamoah, 2004; Anim-Kwapong et al., 2007; Adzaho et al., 2015).

\subsubsection{Institutional Innovations}

The cocoa sector is one of the few with strong policies for effective management of the industry. There are clearly formulated policies and regulations to guide actors roles and actions completely from planting the seedlings through the tedious activities of cultivating the crop to harvesting and going into internal marketing and then through the ports to the external buyers. Some forms of institutional innovations emerged from the exploratory study of the cocoa sector. The Government/COCOBOD has implemented a number of policies and interventions in the cocoa sub-sector of the economy. These include cocoa producer price policy; cocoa pest and disease control programme (CODAPEC), that is, mass spraying exercise; Cocoa High Technology programme (Hi-Tech); Cocoa Swollen Shoot Disease Control (CSSVDC) programme; Mistletoe Removal programme; Cocoa Rehabilitation programme; cocoa extension public-private partnership; deregulation of the internal marketing; and promotion of organic and fair-trade cocoa

\subsubsection{Producer Price Policy}

It is the policy of the government to adjust the cocoa producer price annually by COCOBOD as a percentage share of free on board (FOB) value to ensure a direct link between Ghana producer price and the world price. Also, this price adjustment is to achieve competitiveness of Ghana's in relation to prices in the neighbouring country (Ministry of finance, 1998). The main objectives of this pricing framework were to: improve upon farmers' real returns from cocoa to ensure the provision of adequate incentives for improved husbandry practices that will increase cocoa yields and output; maximize Ghana's foreign exchange earnings from cocoa while ensuring reasonable tax revenue for government; and providing adequate returns to other stakeholders. The Producer Price Review Committee (PPRC) is responsible for determination of producer price of cocoa considering US dollar, fluctuations in the exchange rate and the projected average exchange rate for the cocoa year. The major determinants of producer prices include international market prices, internal transportation, shipping periods, buying patterns, product quality, export taxes, packing and handling costs, farmers' cost of production and profit margins (COCOBOD, 2000). The constraints associated with the cocoa producer price policy are the problems of the Pan-Territorial system, namely, the bureaucracy cost of the system; farmers are paid the same price of cocoa irrespective of the grade of the cocoa beans and; encouragement of cocoa production in marginal forest areas at the expense of the environment and at high costs. The differential producer price in favour of that prevailing in the neighbouring countries causes cocoa smuggling (Ministry of finance, 1998)

\subsubsection{Cocoa Pest and Disease Control Programme (CODAPEC)}

The CODAPEC programme was instituted by Government/COCOBOD to assist the cocoa farmers in the control of pests (capsids/mirids) (CRIG, 2006; CRIG, 2008) and diseases (black pod) (CRIG, 2006; CRIG, 2007; CRIG, 2008; CRIG, 2014) of cocoa in all the cocoa growing regions of the country in 2001/02 (Agyinah \& Opoku, 2010; CRIG, 2011; CRIG, 2012). Additional aims were to train farmers and technical personnel on the cultural and chemical methods of pests and diseases control, educate and train local sprayers on safe pesticides application, increase farmers' income and reduce youth unemployment in the rural communities (Agyinah \& Opoku, 2010). According to them, challenges of the CODAPEC programme include: lack of adequate co-operation from farmers; inadequate spraying gangs led to partial coverage of farms; lack of reliable statistical 
data on cocoa farmers and their farm sizes; charging of fees by some Spraying Gangs from farmers before farms were sprayed; and pilfering and diversion of inputs were the biggest challenges of the programme. Currently, CODAPEC continues to face challenges such as: late arrival of agro-inputs like chemicals (pesticides), fuel, motorized pneumatic spraying machines, etc.; late payment of allowances for CODAPEC sprayers; inadequate gangs; gang formation restricted to COCOBOD alone; huge cost of the programme; excessive involvement of politicians in the programme; and opinion leaders including some chief farmers 'hijack' the pesticides and other inputs (Agyinah \& Opoku, 2010).

\subsubsection{Cocoa High Technology Programme (Hi-Tech)}

The Cocoa High Technology (Hi-Tech) programme was introduced by Government/COCOBOD in 2002/2003 season as a response to low soil fertility of cocoa farms because of prolonged depletion of plant nutrients in the soil by crop absorption (CRIG, 2011; CRIG, 2014). The programme entailed the provision of fertilizers such as Sidalco liquid fertilizer, Cocofeed, Asaase wura and Ammonium Sulphate ('Ammonia') to cocoa farmers for application to replenish the lost nutrients to increase cocoa output (CRIG, 2011). Currently, the Hi-Tech programme encounters some problems including: low subsidy on inputs, resulting in increased price of fertilizer; farmers do not stick to the recommended rates of application of the fertilizers; and late arrival of fertilizers. The latest fertilizer policy of the government, since 2014, has been the provision of free fertilizers to cocoa farmers to enhance its use on cocoa farms.

\subsubsection{Cocoa Swollen Shoot Disease Control Programme}

Currently, the Cocoa Swollen Shoot Virus Disease Control Unit (CSSVDCU) now renamed as Cocoa Health and Extension Division (CHED), previously the Cocoa Services Division (CSD), is responsible for the survey and control of the Cocoa Swollen Shoot Virus disease (CSSVD) (CRIG, 2014; Domfeh et al., 2008), and cocoa extension (COCOBOD, 2013). The Unit's activities include the removal and destruction of swollen shoot diseased cocoa trees from the farms and supply of CSSV resistant hybrid cocoa variety (CRIG, 2007) to the farmers for replanting. The Unit occasionally conducts rallies aimed at educating the farmers on the CSSVD to enable them to report such cases to the Unit for the necessary action to be taken. The CSSVD control programme has been facing some challenges including: opposition of some farmers to the cutting of the diseased trees because of lack of money to replant and to maintain the household, old age of some farmers who depend on the farm for survival, late payment of compensation as well as the land tenure systems, that is, caretaking/abusa/abunu systems (Aneani et al., 2013)

\subsubsection{Mistletoe Control Programme}

The mistletoe (Tapinanthus bangwensis) control programme was instituted in 2011. The purpose of this programme has been to remove all the mistletoes which are parasitic plants on cocoa trees (CRIG, 2012). Unfortunately, the contractors or team face problems such as lack of protective clothing especially goggles to protect the eyes and nose from the wood dust, insect bites, inadequate allowance paid to the casual workers for the mistletoe removal, weak standard pruners with lack of sharpening tool/file, non-payment of accommodation cost and traveling allowance (T\&T) for the mistletoe team, leading to inefficient work, etc. (Aneani et al. 2013). Now the control programme has been integrated with the Cocoa Rehabilitation programme as a second component (COCOBOD, 2013).

\subsubsection{Cocoa Rehabilitation Programme}

The national cocoa rehabilitation programme was launched in Goaso, in the Brong-Ahafo Region by Ghana Cocoa Board (COCOBOD), on the theme: "Increased and Sustainable Cocoa Production for Enhanced Livelihood." The revamping programme started in the second quarter of 2011 and it is expected to continue to 2017. In the programme, Farmers are to register and be provided with the best seedlings and technical know-how to increase production and income levels in their various locations (COCOBOD, 2013). The project involves among other things, application of fertilizers, removal of mistletoes, cutting down over-aged and diseased trees, and replanting of farms with hybrid and high-yielding seedlings. There is also free supply of plantain suckers and economic tree seedlings so that after harvesting the cocoa, the farmers could also benefit financially from these species all year round (COCOBOD, 2013). The Government has put measures in place to ensure that cocoa trees planted more than 25 years ago are cut down, and the farmers would receive compensation for this. However, the establishment of new cocoa farms in the forest reserves is strictly not part of the rehabilitation programme. The 19 million-Ghana Cedi ( $\$ 10$ million) programme was expected to provide 20 million seedlings to farmers and create 2,000 jobs for the youth who will nurse the young trees (COCOBOD, 2013). However, farmers on the scheme complained of inadequate supply of seedlings and irregular payment of the compensation. The project has been encountering challenges including inadequate funds to support farmers to pay for labour 
cost and some difficulty in gaining the cooperation of some farmers in the diseased tree cutting process (Aneani et al., 2013).

\subsubsection{Cocoa Extension}

The Cocoa Services Division (CSD), now Cocoa Swollen Shoot Virus Disease Control Unit (CSSVDCU) which has been renamed as Cocoa Health and Extension Division (CHED), with its Head Office in Accra, controls the CSSVD in addition to providing extension services involving cocoa production technologies and best farm practices to farmers to solve problems and to obtain knowledge and information, skills, and technologies to improve their livelihoods and well-being (Asenso-Okyere et al., 2008; Birner et al., 2006). Traditional and unified extension services were criticized for being supply-driven, not driven by the users (farmers); highly centralized; non-participatory (dominated by a single channel of knowledge transfer); exclusive of the poor; inefficiency etc. (Asenso-Okyere, et al., 2008; Birner et al., 2006; Barrientos et al., 2008). In June 1998, Government of Ghana decided that the extension services of Ministry of Food and Agriculture (MoFA) and CSD be unified to reduce costs and improve efficiency in the delivery of extension services to farmers. Subsequently, a committee was put in place to draw up modalities for the merger. Government was to provide adequate financial logistic support to MoFA to enable it to provide effective agricultural extension services to the farmers (COCOBOD, 2001). Under this merger cocoa extension was inadequate due to insufficient logistic support.

Currently, a new cocoa extension programme, the Cocoa Extension Public-Private Partnership (CEPPP), has been introduced since 2011 to disseminate latest cocoa production technologies available to farmers (COCOBOD, 2012; COCOBOD, 2013). The operation of the new system is based on the principle of lean staff number who are professionally trained and highly qualified and motivated to deliver cost-effective and efficient cocoa extension service to business-oriented farmers ready to demand services and be owners of cocoa extension. The objectives of the CEPPP are to: provide an efficient and cost-effective extension to cocoa farmers to increase their productivity; assist farmers to acquire knowledge and skills to be able to adopt good agricultural practices (GAP); orientate and train cocoa farmers in basic farm economics for them to consider cocoa farming as a rewarding business; educate and encourage farmers to own cocoa extension; encourage the youth to take cocoa cultivation; strengthen Farmer Group (FGs) to access inputs/credits; build the capacity of extension staff to deliver training to farmers; and build the capacities for effective monitoring and evaluation (COCOBOD, 2012; COCOBOD, 2013).

According to COCOBOD (2012) and COCOBOD (2013), the public sector partners of the CEPPP comprise Ghana Cocoa Board and its subsidiaries such as Cocoa Swollen Shoot Virus Control Unit (CSSVDCU), Cocoa Research Institute of Ghana (CRIG), Quality Control Co. Ltd (QCCL), Seed Production Unit (SPU). The private sector partners consist of Kraft Foods (Cadbury), West African Fair Fruit (WAFF), World Cocoa Foundation/Cocoa Livelihoods Programme (WCF/CLP) and allied agencies, Armajaro Ghana limited, Rainforest Alliance and Farmers. These partners fund the recruitment, remuneration, and training of the extension agents. Also, they jointly provide for training materials, publications and the cost of training farmers. In addition, Deutsche Gesellschaft für Internationale Zusammenarbeit (GIZ) $\mathrm{GmbH} /$ Sustainable Cocoa Business in collaboration with the other partners support the training of farmers in Farmer Business School (FBS) and the design of extension tools. The CSSVDCU co-ordinates CEPPP and supported by partners and stakeholders. Also, the National Steering Committee for cocoa extension oversees the new Cocoa Extension system. The Cocoa Research Extension Technical Committee (CRETEC) ensures effective link between Farmer-Extension-Research (MASDAR, 1998; COCOBOD, 2001). Additionally, the Monitoring Unit at CSSVDCU and the Evaluation Unit at Cocoa Research Institute of Ghana, Social Science and Statistics Unit compile and evaluate data on the progress of the partnership's activities. As achievements since 2010, the CEPPP has documented all the technologies developed by CRIG into a cocoa sourcebook as its knowledge base (Opoku-Ameyaw et al., 2010). In addition, the programme has developed innovative extension tools of technical advice with management and social issues. The CEPPP has also adopted the Farmer Business School (FBS) Approach developed by GIZ in the framework of Cocoa Livelihoods Programme for the strengthening of farmers' capacities to understand the income potential of improved production techniques of cocoa and food crops (COCOBOD, 2012).

Another programme under the formation of public-private partnerships (PPPs) in cocoa extension is the Cadbury Cocoa Partnership. This partnership links the COCOBOD and Cadbury International to implement extension services in selected cocoa-producing communities to improve cocoa production. The main goals of the partnership are to: promote sustainable livelihoods for one million cocoa farmers; increase crop yields for farmers participating in the programme by 20 percent in 2012 and 100 percent in 2018; create new sources of income in 100 cocoa -farming communities in Ghana; and deal with major issues affecting the cocoa sector such as child labour, health, gender diversity, and environmental sustainability. 


\subsubsection{Deregulation of the Internal Marketing}

A key institutional reform was the deregulation of the internal marketing of cocoa with the promotion of private involvement to allow competition. Also, the private involvement was meant to introduce efficiency into the market.

\subsubsection{Promotion of Organic and Fair-trade Cocoa}

Another institutional change was the promotion of farmers' involvement in the production of organic and fair-trade cocoa which attract higher premiums on the export market.

\section{Conclusions and Recommendations}

Conclusions drawn from the findings of this study are as follows:

- This study identified key stakeholders/actors such as Ghana Cocoa Board (COCOBOD) with the subsidiaries; the private licensed buying companies (LBCs); private processing companies; cocoa farmers; and farmer association, with their specific roles in the cocoa industry.

- Cocoa production activities identified could be categorized into farm establishment operations (including land acquisition, land clearing and preparation, lining and pegging of the farm, nursing of the seedlings in the nursery for later transplanting to the field, and planting at stake of cocoa seeds), farm maintenance operations (including manual weeding /herbicide application; pruning; capsid control, that is, spraying insecticides against capsids; black pod disease control, that is spraying fungicides; fertilizer application; shade management; and mistletoe control) and primary processing activities (including harvesting of cocoa pods, pod gathering and heaping, pod breaking, fermentation, removal of fermented beans, and drying of cocoa beans).

- Some cocoa production and marketing constraints were identified and the key constraints were: Black pod disease; Pests and parasites; Cocoa swollen shoot virus disease (CSSVD); Infrequent and inadequate extension service; Declined soil fertility; Marketing constraints; Lack of credit to farmers; High cost and unavailability of farm inputs; Illegal mining (Galamsay); and Inadequate seedlings/planting material supply

Recommendations based on the findings of this study include:

- The number of seed gardens should be increased and equitably distributed in cocoa districts and adequately resourced by Government/COCOBOD to enable them to produce sufficient hybrid seed pods. This would enhance the farmers' access to hybrid pods and reduce the possibility of planting unapproved seeds and planting materials.

- More extension agents should be employed, trained, well-resourced and adequately supervised to ensure effective, efficient and timely dissemination of improved cocoa production practices/technologies such as application of pesticides and fertilizers to the farmers for adoption.

- To increase the adoption rates of the improved production practices/technologies, Government/COCOBOD should encourage farmers to form village level associations which could provide some guarantee of payment and simultaneously encourage rural banks to provide effective, efficient and adequate credit through such arrangements.

- Government/COCOBOD should completely liberalized the chemical input and spraying machine supply by encouraging private sector participation and assisting these small businesses in underwriting loans, licensing, publicity, training, and ensuring reasonable input prices. This would increase accessibility and timely supply of inputs/agro-chemicals and enhance adequate implementation of improved disease and pest control practices at the right time by farmers.

- Illegal mining (Galamsay) causes much destruction to cocoa farms and adds to the uncertainty that farmers face when choosing to plant cocoa. Efforts should be made to identify illegal miners and to record cases where compensation has not been paid by legal concession holders. The misery that miners inflict on farmers in addition to the damage they cause to the soil means that punishment should be severe enough to serve as deterrent instead of the small financial compensations that are agreed on. Land rights are held by the stool and concessions are granted to the illegal miners by the landowners. If government could control illegal mining, only a proportion of the value of the gold would need to be paid to farmers without transferring rights from stool or concession holders. The illegal miners should be made to rehabilitate or reclaim the destroyed lands which are suitable for cocoa production. However, considering the negative impact on the ecosystem, the national economy, farmer insecurity at old age, 
the inability to reclaim mined lands, water pollution, high cost of living in mining communities, health hazards and other possible threats to the cocoa industry, it is therefore not prudent for mining to be allowed on cocoa farms.

- The Cocoa Swollen Shoot Virus Disease (CSSVD) is an important disease which has no chemical cure, but the only remedy is cutting out of the diseased trees and their immediate contiguous ones. Therefore, Government/COCOBOD should improve the transparency, efficiency and timeliness of the tree cutting and ex-gratia payment. In addition, mass campaign/awareness building on the presence of the disease based on symptom identification and promotion of better agronomic practices should be continued.

- Market constraints such as weighing scale adjustment, low cocoa producer price, malpractices of the DOs and PCs of the LBCs, poor drying and admixture of beans by some farmers that compromise the quality of cocoa, etc. should be addressed by Government/COCOBOD in collaboration with the LBCs, PCs and farmers. For instance, the effort being made in the introduction and piloting of the weighing stone concept should be intensified and its usage made mandatory to the LBCs in their purchasing of cocoa.

- The Government/COCOBOD should intensify its efforts in implementing the opportunities identified in this study to enhance farmers' welfare and the development of the entire cocoa industry. Addressing these constraints requires collaboration among the various stakeholders in the sector, including the government, research and extension as well as smallholder farmers. Promoting cocoa sector development in Ghana requires institutional conditions that will encourage smallholder cocoa farmers to use modern technologies of production and marketing to improve their incomes.

\section{Acknowledgements}

The support provided by the technical staff, Mr. Dickson Agyapong and Mr. Moses Asani, of the Social Science and Statistics Unit of Cocoa Research Institute of Ghana (CRIG) is gratefully acknowledged. The research was supported by funds from the Cos-SIS programme. This paper, CRIG/002/2015/045/007, is published with the permission of the Executive Director, CRIG, Tafo.

\section{References}

Adjie-Nsiah, S., Sakyi-Dawson, O., \& Kuyper, I. W. (2012). Exploring opportunities for enhancing innovation in agriculture: the case of oil palm production in Ghana. Journal of Agricultural Science, 4(10), 212-223. https://doi.org/10.5539/jas.v4n10p212

Adjinah, K. O., \& Opoku, I. Y. (2010). The national cocoa diseases and pest control (CODAPEC): Achievements and challenges. Retrieved on November 24, 2010.

Adzaho, D.K., Opoku-Asiama, Y., Adu-Ampomah, Y., \& Takrama, J. F. (2015). Effect of fermentation on nib acidity, fermentation index and residual anthocyanin content in dry cocoa beans. Journal of the Ghana Science Association, 16(1), 16-25.

Akerlof, G. A. (1970). The market for "lemons": quality uncertainty and market. Journal of economics, 84, 488-500. https://doi.org/10.2307/1879431

Ameyaw, G. A., Johnson Victress, Dzahini-Obiatey, H., \& Domfeh, O. (2013). A manual on laboratory transmission, inoculation and indexing for cocoa swollen shoot virus disease (CSSVD). Technical Bulletin No. 25. New Tafo-Akim, Ghana: Cocoa Research Institute of Ghana (CRIG) (Ghana Cocoa Board). 23pp.

Amponsah-Tawiah, K., \& Dartey-Baah, K. (2011). The mining industry in Ghana: A blessing or a curse. International Journal of Business and Social Science, 2(12), 62-69.

Aneani, F., \& Asamoah, M. (2004). Socio-economic survey on cocoa fermentation in Ghana. Journal of Ghana Science Association, 6(2), 90-97.

Aneani, F., Adu-Acheampong, R., \& Oppong, F. K. (2013). Convergence of sciences strengthening agricultural innovation systems (CoS-SIS) institutionalization research programme: An exploratory study of the cocoa industry in Ghana. A Final Report Submitted to National Co-ordinator, CoS-SIS Secretariate, Extension Department, College of Agriculture and Consumer Science, University of Ghana, Accra. 73pp.

Aneani, F., Anchirinah, V. M., Asamoah, M., \& Owusu-Ansah, F. (2007). Baseline socio-economic and farm managements survey. A Final Report for the Ghana Cocoa Farmers' Newspaper Project. New Tafo-Akim, Ghana: Cocoa Research Institute of Ghana (CRIG) (Ghana Cocoa Board).

Anim-Kwapong, E., Appiah, M. R., \& Osei-Bonsu, K. (2007). A review of the factors affecting the quality of 
processed cocoa beans in Ghana. Journal of the Ghana Science Association, 9(1), 106-119.

Asenso-Okyere, K., Davis, K., \& Aredo, D. (2008). Advancing agriculture in developing countries through knowledge and innovation. Synopsis of an international conference, Washington, D.C.: International Food Policy Research Institute.

Barrientos, S., Asenso-Okyere, K., Asuming-Brempong, S., Sarpong, D., Anyidoho, N. A., Leavy, J., \& Kaplinsky, R. (2008). Mapping sustainable production in Ghanaian cocoa. London, UK: Cadbury.

Birner, R., Davis, K., Pender, J., Nkonya, E., Anandajayasekeram, P., Ekboir, J., Mbabu, A., Spielman, D., Horna, D., Benin, S., \& Cohen, M. (2006). From best practice to best fit: a framework for designing and analyzing agricultural advisory services. ISNAR Discussion Paper 5, Washinton, D.C., USA: International Food Policy Research Institute.

COCOBOD (2001). Proceedings of the one-day seminar on the CSD/MOFA extension merger held at Bunso Cocoa College, $14^{\mathrm{TH}}$ May 2000, CSD/MOFA Extension Merger Monitoring Committee, Ghana Cocoa Board, Accra. June, 2001.

COCOBOD (2012). Cocoa extension public-private partnership in Ghana. A report on a refresher training, 9-10 ${ }^{\text {th }}$ February 2012 at Bunso Cocoa College, Accra: Ghana Cocoa Board (COCOBOD). 50pp.

COCOBOD (2013). Focus on CSSVD-CU-Part II: National Cocoa Rehabilitation Programme an Opportunity for Increased and Sustainable Cocoa Production for Enhanced Livelihood of the Cocoa Farmers. Ghana Cocoa Board (COCOBOD) News, December 2013 edition.

COCOBOD. (2000). Comments by COCOBOD management on the LMC International school of administration, University of Ghana Report on Liberalization of External Marketing of Cocoa in Ghana, January 2000, Ghana Cocoa Board, Accra.

CRIG. (1996). A guide to harvesting, fermentation, drying and storage of cocoa. Farmers Guide No. 7. New Tafo-Akim, Ghana: Cocoa Research Institute of Ghana (CRIG)

CRIG. (2011). Ghana cocoa farmers newspaper. Bi-annual Technical Information for Cocoa Farmers, Issue No. 007, New Tafo-Akim. Ghana: Cocoa Research Institute of Ghana (Ghana Cocoa Board)

CRIG. (2012). Ghana cocoa farmers newspaper. Bi-annual Technical Information for Cocoa Farmers, Issue No. 008, New Tafo-Akim, Ghana: Cocoa Research Institute of Ghana (Ghana Cocoa Board).

CRIG. (2014). Ghana cocoa farmers newspaper. Bi-annual Technical Information for Cocoa Farmers, Special Edition, New Tafo-Akim, Ghana: Cocoa Research Institute of Ghana (Ghana Cocoa Board),

Domfeh, O., Johnson Victress, Dzahini-Obiatey, H. \& Akumfi-Ameyaw, G. (2008). Cocoa swollen shoot virus disease and control. Technical Bulletin No. 17. New Tafo-Akim, Ghana: Cocoa Research Institute of Ghana (CRIG) (Ghana Cocoa Board). 20pp.

Donkor, M. A., Henderson, C. P., \& Jones, A. P. (1991). Survey to quantify adoption of CRIG recommendations. Cocoa Research Institute of Ghana (CRIG), Farming Systems Unit Research Paper No. 3, p29.

Gosling, L., \& Edwards, M. (2003). Toolkits: A practical guide to planning, monitoring, evaluation and impact assessment. Development Manual. London, UK: Save the Children. 302-307.

Henderson, C. P., \& Jones, A. P. (1990). Analysis of constraints to the adoption of CRIG recommendations in Offinso Districts: results and discussion. CRIG farming systems Unit Research. Paper No. 1 CRIG, Tafo, Ghana, p15.

Hilson, G. (2001). A contextual review of the Ghanaian small-scale mining industry. A report commissioned by Mining, (IIED), 76, 29.

Hilson, G., \& Putter, C. (2005). Structural adjustment and subsistence industry: artisanal gold mining in Ghana. Development and Change, 36(1), 103-131. https://doi.org/10.1111/j.0012-155X.2005.00404.x

Hounkonnou, D., Kossou, D., Kuyper, T. W., Leeuwis, C., Nederlof, N., Roling, N., Sakyi-Dawson, O, Traore, M., \& van Huis, A. (2012). An innovation systems approach to institutional change: smallholder development in West Africa. Agricultural Systems, 108, 74-83. https://doi.org/10.1016/j.agsy.2012.01.007

Huis, A. van, Hounkonnou, D., \& Roling. N. G. (2007). Preface. International Journal of Agricultural Sustainability, 5, 89-90. https://doi.org/10.1017/CBO9780511611070.001

Johnson, B. (1992). "Institutional learning”. In : B-A. Lundvall (ed.). National Systems of Innovation. London: 
Pinter Publishers.

Klein, P. (1996). New International Economics. Ghent: Edward Elgar and University of Ghent.

MASDAR (1998). Socio-Economic Study. A Final Report, Accra, Ghana: MASDAR Consultants/ Ghana Cocoa Board (COCOBOD).

Ministry of Finance (1998). Ghana cocoa sector development strategy. Task force report, Accra, Ghana:Ministry of finance. pp 61.

Ofosu, S. B. (1995). Ghana's cocoa rehabilitation project in the context of the economic recovery programme/structural adjustment programme: how successful? Visiting Research Fellow Series No. 251, Tokyo: Institute of Developing Economies.

Opoku, I. Y., Assuah, M. K., \& Domfeh, O. (2007). Manual for the Identification and Control of Diseases of Cocoa. Technical Bulletin No. 16, Cocoa Research Institute of Ghana (CRIG), New Tafo-Akim, Ghana.

Opoku-Ameyaw, K., Baah, F., Gyedu-Akoto, E., Anchirinah, V., Dzahini-Obiatey, H., \& Cudjoe, A. R. (2010). Cocoa manual: a source book for sustainable cocoa production. New Tafo-Akim, Ghana: Cocoa Research Institute of Ghana (CRIG) (Ghana Cocoa Board) 


\section{Appendix A}

Table 1. Prioritization of constraints perceived by participants

\begin{tabular}{|c|c|c|c|c|}
\hline Constraint & Frequency & $\begin{array}{l}\text { Average } \\
\text { score }(\%)\end{array}$ & $\begin{array}{l}\text { Multiplication of } \\
\text { frequency and av. Score }\end{array}$ & Ranking/Position \\
\hline Diseases: CSSV, Black Pod (P. parmivora and P. megakarya) & 4 & 44.4 & 177.6 & 22 \\
\hline Pests and parasites: capsids, termites, stem borer, rodents, mistletoe. & 4 & 75.4 & 301.6 & 11 \\
\hline $\begin{array}{l}\text { Bush fires: aggravated by changes in land use, ecology and climate } \\
\text { change }\end{array}$ & 2 & 9.1 & 18.2 & 35 \\
\hline $\begin{array}{l}\text { Drought: aggravated by changes in land use, ecology and climate } \\
\text { change }\end{array}$ & 4 & 43.3 & 173.2 & 23 \\
\hline Decline soil fertility & 4 & 73.1 & 292.4 & 13 \\
\hline $\begin{array}{l}\text { Low remuneration (rural incomes generally + real value of cocoa } \\
\text { producer price). }\end{array}$ & 4 & 84.3 & 337.2 & 6 \\
\hline Remuneration that is infrequent compared with other crops. & 4 & 59.2 & 236.8 & 19 \\
\hline $\begin{array}{l}\text { Perceived high cost and poor availability of chemical inputs and } \\
\text { spraying machines. }\end{array}$ & 4 & 86.1 & 344.4 & 3 \\
\hline $\begin{array}{l}\text { Perceived high cost and poor availability of non-chemical inputs } \\
\text { such as boots, cutlasses, pruners, spraying machines, etc. }\end{array}$ & 4 & 51.7 & 206.3 & 20 \\
\hline $\begin{array}{l}\text { Occasional poor availability and perceived high cost of seedlings } \\
\text { and poly (rooting) bags. }\end{array}$ & 4 & 68.0 & 272.0 & 16 \\
\hline Occasional poor availability and perceived high cost of casual labour & 4 & 66.2 & 264.8 & 17 \\
\hline $\begin{array}{l}\text { High rates of time preference leading to discounting of future } \\
\text { incomes and risks }\end{array}$ & 4 & 64.2 & 256,8 & 18 \\
\hline Poor standard of cocoa buying and marketing-widespread abuses & 4 & 85.3 & 341.2 & 5 \\
\hline Infrequent and inadequate extension advice & 4 & 78.1 & 312.4 & 9 \\
\hline High average age of farmers leading to poor husbandry & 4 & 79.9 & 319.6 & 7 \\
\hline $\begin{array}{l}\text { Poor status of farming, low incomes, employment opportunities \& } \\
\text { rural facilities }\end{array}$ & 4 & 92.7 & 370.8 & 1 \\
\hline $\begin{array}{l}\text { Poor health arising largely from poor standard of rural life and } \\
\text { medical facilities }\end{array}$ & 1 & 17.9 & 17.9 & 36 \\
\hline Low education standards and literacy rates & 4 & 74.2 & 296.8 & 12 \\
\hline $\begin{array}{l}\text { Lack of self-reliance (an expectation that government should or will } \\
\text { provide) }\end{array}$ & 3 & 59.9 & 179.7 & 21 \\
\hline $\begin{array}{l}\text { Rising rural population and diminishing supply of new land, land for } \\
\text { food crops, reduced fallow }\end{array}$ & 4 & 73.1 & 292.4 & 14 \\
\hline Ill-defined inheritance systems & 3 & 26.0 & 78.0 & 31 \\
\hline Farm fragmentation & 4 & 73.1 & 292.4 & 15 \\
\hline $\begin{array}{l}\text { Insecurity of tenure, especially among migrants-harassment by local } \\
\text { chiefs/ landowners }\end{array}$ & 2 & 32.1 & 64.2 & 33 \\
\hline Disenfranchment of local people & 2 & 68.7 & 137.4 & 24 \\
\hline Low remuneration from abusa caretaking & 1 & 92.6 & 92.6 & 29 \\
\hline $\begin{array}{l}\text { Social obligations, funerals-restricting time available for active } \\
\text { farming }\end{array}$ & 2 & 46.3 & 92.6 & 30 \\
\hline Illegal logging & 2 & 53.9 & 107.8 & 25 \\
\hline Gender: Unequal access to inputs and labour & 2 & 33.0 & 66.0 & 32 \\
\hline Poor access to credit facilities & 4 & 79.5 & 318.0 & 8 \\
\hline Poor road network in their communities & 4 & 85.6 & 342.4 & 4 \\
\hline Delays in bonus payment & 4 & 89.0 & 356.0 & 2 \\
\hline Incidence of epiphytes in cocoa farms & 4 & 78.1 & 312.4 & 10 \\
\hline Cherewilt & 1 & 53.6 & 53.6 & 34 \\
\hline Destruction of cocoa by galamsey (small-scale mining) & 1 & 100.0 & 100.0 & 26 \\
\hline Poor association & 1 & 100.0 & 100.0 & 27 \\
\hline Scholarship & 1 & 100.0 & 100.0 & 28 \\
\hline
\end{tabular}


Table 2. Categorization of constraints perceived by farmers into technical, socio-economic, social and institutional

\begin{tabular}{|c|c|}
\hline Category & Constraint \\
\hline Technical & $\begin{array}{l}\text { Diseases: CSSV, B lack Pod (P. parmivora and P. megakarya). } \\
\text { Pests and parasites: capsids, termites, stem borer, rodents, mistletoe. } \\
\text { Bush fires: aggravated by changes in land use, ecology and climate change. } \\
\text { Drought: aggravated by changes in land use, ecology and climate change. } \\
\text { Decline soil fertility. } \\
\text { Incidence of epiphytes in cocoa farms } \\
\text { Cherewilt }\end{array}$ \\
\hline Socio-economic & $\begin{array}{l}\text { Low remuneration (rural incomes generally + real value of cocoa producer price). } \\
\text { Remuneration that is infrequent compared with other crops. } \\
\text { Perceived high cost and poor availability of chemical inputs and spraying machines. } \\
\text { Perceived high cost and poor availability of non-chemical inputs such as boots, cutlasses, } \\
\text { pruners, spraying machines, etc. } \\
\text { Occasional poor availability and perceived high cost of seedlings and poly (rooting) bags. } \\
\text { Occasional poor availability and perceived high cost of casual labour } \\
\text { High rates of time preference leading to discounting of future incomes and risks } \\
\text { Poor standard of cocoa buying and marketing-widespread abuses. } \\
\text { Delays in bonus payment. }\end{array}$ \\
\hline Social & $\begin{array}{l}\text { High average age of farmers leading to poor husbandry. } \\
\text { Poor status of farming, low incomes, employment opportunities \& rural facilities. } \\
\text { Poor health arising largely from poor standard of rural life and medical facilities. } \\
\text { Low education standards and literacy rates. } \\
\text { Lack of self-reliance (an expectation that government should or will provide). } \\
\text { Rising rural population and diminishing supply of new land, land for food crops, reduced fallow. } \\
\text { Poor association of farmers. }\end{array}$ \\
\hline Institutional & $\begin{array}{l}\text { Ill-defined inheritance systems } \\
\text { Farm fragmentation } \\
\text { Insecurity of tenure, especially among migrants-harassment by local chiefs/ landowners } \\
\text { Disenfranchment of local people by migrants } \\
\text { Low remuneration from abusa caretaking. } \\
\text { Social obligations, funerals-restricting time available for active farming. } \\
\text { Illegal logging. } \\
\text { Gender: Unequal access to inputs and labour and Unequal time spent on social obligations } \\
\text { Poor access to credit facilities. } \\
\text { Poor road network in their communities. } \\
\text { Infrequent and inadequate extension advice. } \\
\text { Destruction of cocoa by galamsey (illegal small-scale mining). } \\
\text { COCOBOD Scholarship. }\end{array}$ \\
\hline
\end{tabular}

\section{Copyrights}

Copyright for this article is retained by the author(s), with first publication rights granted to the journal.

This is an open-access article distributed under the terms and conditions of the Creative Commons Attribution license (http://creativecommons.org/licenses/by/3.0/). 